\title{
First Records of Red Cornsnakes (Pantherophis guttatus) from Abaco Island, The Bahamas, and Notes on Their Current Distribution in the Greater Caribbean Region
}

\author{
Sean T. Giery \\ Department of Biology, Marine Science Program, Florida International University, North Miami, Florida 33181 (stgiery@gmail.com)
}

Red Cornsnakes on Abaco Island, The Bahamas

Red Cornsnakes (Pantherophis guttata) were first recorded in The Bahamas in the mid-1990s on Grand Bahama Island (Buckner and Franz 1987), with subsequent reports elsewhere on Grand Bahama (Little Bahama Bank) and New Providence (Great Bahama Bank) (Knapp et al. 2011, Buckner et al. 2012). Here, I report the first observations of Red Cornsnakes on Abaco Island, a large island $(-165 \mathrm{~km}$ long) of the Little Bahama Bank at the northeastern edge of The Bahamas Archipelago. These observations extend the known range of introduced populations of Red Cornsnakes in The Bahamas and exemplify the spread of the species throughout the greater Caribbean region.

I collected two Red Cornsnakes (Figs. 1 \& 2) on Abaco Island, The Bahamas in October and December 2012 near the town of Cherokee on the eastern coast of Abaco. No available data point to the origin(s) of these snakes. The identification was confirmed by Dr. Kenneth L. Krysko, Florida Museum of Natural History. Collection sites were within 1 $\mathrm{km}$ of one another. Both snakes were found in a low-density residential area dominated by low, evergreen forest (coppice)

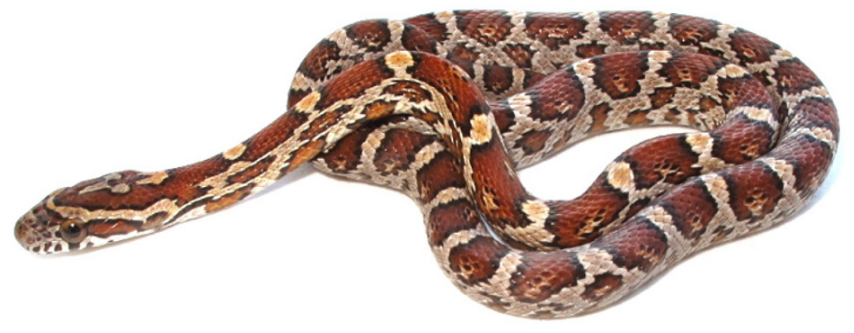

Fig. 1. Hatchling Red Cornsnake (Pantherophis guttatus) found alive on 25 October 2012 near Cherokee Sound, Abaco Island, The Bahamas (26.2835/-77.03469) (UF 169221).

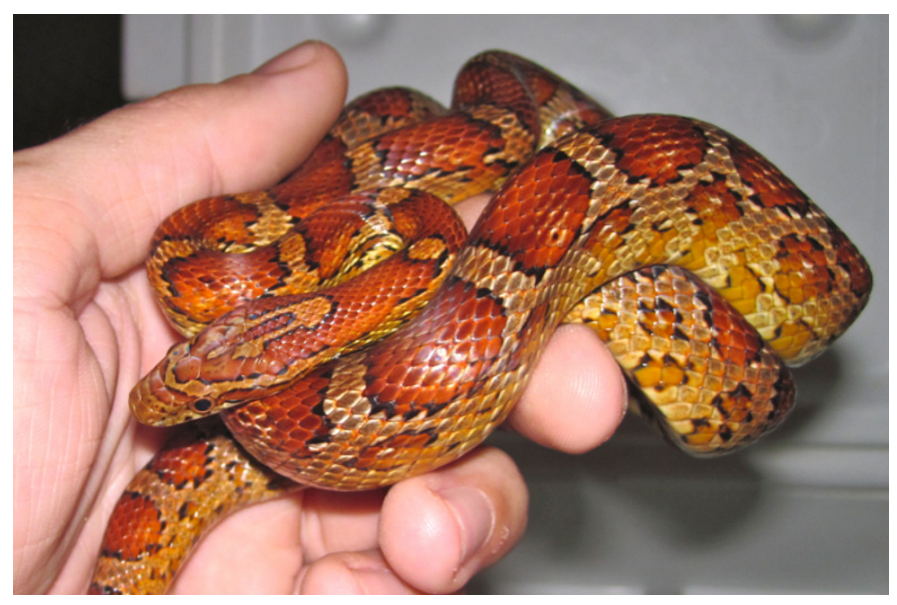

Fig. 2. Adult Red Cornsnake (Pantherophis guttatus) found alive on 2 December 2012 near Cherokee Sound, Abaco Island, The Bahamas (26.29015/-77.03432) (UF 169222).

consisting of Thatch Palm (Thrinax radiata), Mahogany (Swietenia sp.), Poisonwood (Metopium toxiferum), and Gumbo Limbo (Bursera simaruba).

\section{Red Cornsnakes in the Caribbean Region}

Red Cornsnakes have been found throughout the greater Caribbean region, with records from 16 different islands and islets within the Lesser Antilles, Cayman Islands, Virgin Islands, the Bahamas Archipelago, and continental islands off the northern coast of South America (Table 1). Until 2000, only four observations of Red Cornsnakes had been recorded in the region (Fig. 3). However, over the last 13 years this number has increased to $>15$ (Table 1). While some of these observations are of single individuals (often deemed "waifs") and do not constitute established (i.e., breeding) populations, these records do indicate a continued introduction of individuals to new islands. In several instances, for example, records 

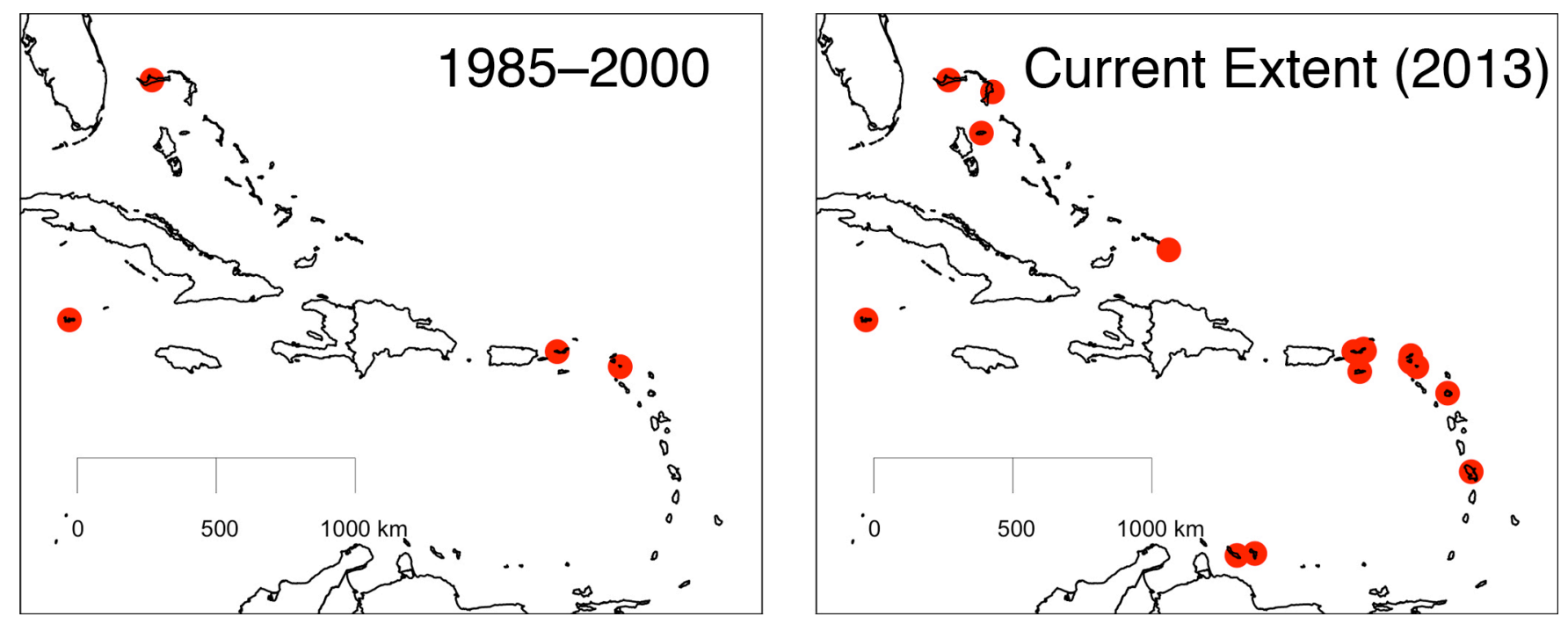

Fig. 3. Distribution of Red Cornsnakes (Pantherophis guttatus) in the Caribbean region. The left panel shows the distribution prior to 2000 and the right panel shows the distribution in 2013. The date of first observation is not reported for several records; the date of publication is used in those instances.

Table 1. Published records of Red Cornsnakes (Pantherophis guttatus) in the greater Caribbean (defined as including the Bahamas, Greater and Lesser Antilles, and continental islands off the northern coast of South America). Note that the U.S. and British Virgin Islands (USVI and BVI, respectively), except for St. Croix, are part of the Puerto Rico Bank.

\begin{tabular}{|c|c|c|c|}
\hline Year* & Island & No. Observed & Selected Citations \\
\hline 1985 & Grand Cayman & multiple & Franz et al. 1987, Echternacht et al. 2011 \\
\hline 1993 & Grand Bahama & 5 & Buckner and Franz 1994, Hayes et al. 2004 \\
\hline 1995 & Saint-Barthélemy & 15 & Breuil 2002, Questel and Vitry 2012 \\
\hline $1990 \mathrm{~s}$ & St. Thomas (USVI) & multiple & Perry et al. 2003; Platenberg and Boulon 2006, Platenberg 2007 \\
\hline 2001 & Curaçao & multiple & Perry et al. 2003, van Buurt 2006 \\
\hline 2002 & Bonaire & $\mathrm{nr}$ & Perry et al. 2003, van Buurt 2006 \\
\hline 2003 & Anguilla & 2 & Hodge et al. 2003, Hodge et al. 2011 \\
\hline 2003 & Antigua & $\mathrm{nr}$ & Kairo et al. 2003 \\
\hline 2005 & Martinique & multiple & Breuil 2009 \\
\hline 2006 & Little St. James (USVI) & 1 & Perry and Platenberg 2007 \\
\hline 2006 & St. Martin & $\mathrm{nr}$ & Powell 2006 \\
\hline 2006 & Tortola (BVI) & multiple & Perry and Gerber 2006 \\
\hline 2007 & St. Croix (USVI) & $\mathrm{nr}$ & Platenberg and Boulon 2006 \\
\hline 2008 & Peter Island (BVI) & 2 & Perry and Gerber 2006 \\
\hline 2010 & Grand Turk & 3 & Reynolds and Niemiller 2010 \\
\hline 2010 & New Providence & $\mathrm{nr}$ & Knapp et al. 2011 \\
\hline 2012 & Abaco & 2 & this study \\
\hline 2012 & Guana Cay (off St. Martin) & $\mathrm{nr}$ & Henderson and Breuil 2012 \\
\hline
\end{tabular}

*Year of first observation if available; if not, the year of publication is listed $\mathrm{nr}=$ not reported 
from St. Thomas (USVI) and St.-Barthélemy (Platenberg 2007, Questel and Vitry 2012, respectively), the first observations of individuals preceded detection of established populations by at least a decade. This lag between initial detection of Red Cornsnakes on an island and the subsequent observation of breeding populations is not surprising given their cryptic habits (Ernst and Ernst 2003), which makes detection probabilities low.

As with other introduced reptiles, introductions of Red Cornsnakes into the region have been attributed to the pet trade or, more frequently, to the international trade in landscaping plants and building materials (Powell et al. 2011). In fact, several records report direct observation of Red Cornsnakes being transported on landscaping plants to the Cayman Islands (Franz et al. 1987), Virgin Islands (Perry and Plantenberg 2007), and Curaçao (van Buurt 2006).

Although most reports correlate arrivals of non-native reptiles in the region with goods coming from Florida (e.g., Powell et al. 2011), the wide geographic spread of observations within the Caribbean region could reflect a stage in the species' expansion/invasion in which the sources of introductions are other introduced populations, so-called secondary introductions (e.g., Kolbe et al. 2007). Platenberg (2007) cited cargo traffic between St. Thomas and Little St. James Island (USVI) and Tortola (BVI) as likely sources of Red Cornsnakes within the Virgin Islands. Similarly, secondary introductions might have arisen from domestic traffic between Bahamian ports on Abaco, Grand Bahama, and New Providence.

Natural limits to the spread of Red Cornsnakes are possible. Native and introduced predators, including snakes, mongooses, and domestic cats, could control population sizes. Also, van Buurt (2006) suggested that the hot, arid environs of Curaçao and Bonaire are adverse to the establishment of Red Cornsnakes, and, in fact, Red Cornsnakes have been found only in irrigated areas on those islands. Although van Buurt (2006) was correct in noting that the environmental conditions on those islands are particularly harsh, the climates of many Caribbean islands are similar to some portions of the species' native range, notably the Florida Keys. The establishment of breeding populations in the Lesser Antilles, Cayman Islands, and The Bahamas further evinces the suitability of habitats for Red Cornsnakes on many islands in the region.

Platenberg (2007) noted the potential ecological threats of Red Cornsnakes via predation and competition with native faunas. Several endemic Caribbean birds, lizards, and snakes are potentially vulnerable. The catholic diet and broad habitat use of Red Cornsnakes make them potential predators of many of these species. At the moment, most observations are from developed habitats such as commercial ports and constructions sites. However, several observations in the Bahamas are in undeveloped pineland and coppice habitats (Hayes et al.
2004, this study), suggesting that Red Cornsnakes can populate habiats where threatened endemics such as the Bahamas Parrot (Amazona leucocephala bahamensis) and several species of rock iguanas (Cyclura spp.) occur. Competition with native snakes is another concern. A number of Lesser Antillean snake populations are already declining and several species presumably are extinct (Powell and Henderson 2005). Competition with an introduced predator for food could exacerbate these declines.

\section{Acknowledgements}

I thank Kenneth L. Krysko for confirming species identification and for providing assistance with specimen preparation. Craig A. Layman, Robert Powell, and an anonymous reviewer provided helpful comments on the manuscript. Friends of the Environment (www.friendsoftheenvironment.org) provided valuable field support on Abaco.

\section{Literature Cited}

Breuil, M. 2002. Histoire naturelle des amphibiens et reptiles terrestres de l'Archipel Guadeloupéen. Guadeloupe, Saint-Martin, Saint-Barthélemy. Patrimoines Naturels, Paris 54:1-339.

Breuil, M. 2009. The terrestrial herpetofauna of Martinique: Past, present, future. Applied Herpetology 6:123-149 (Reprinted 2011, with addendum, pp. 311-338 in: A. Hailey, B.S. Wilson, and J. Horrocks (eds.), Conservation of Caribbean Island Herpetofaunas. Volume 2: Regional Accounts of the West Indies. Brill Academic Publishers, Leiden, The Netherlands).

Buckner, S.D. and R. Franz. 1994. Geographic distribution: Elaphe guttata. Herpetological Review 25:166.

Buckner, S.D., R. Franz, and R.G. Reynolds. 2012. Bahama Islands and Turks \& Caicos Islands, pp. 93-110. In: R. Powell and R.W. Henderson (eds.), Island lists of West Indian amphibians and reptiles. Bulletin of the Florida Museum of Natural History 51:85-166.

Echternacht, A.C., F.J. Burton, and J.M. Blumenthal. 2011. The amphibians and reptiles of the Cayman Islands: Conservation issues in the face of invasions, pp. 129-147. In: A. Hailey, B.S. Wilson, and J. Horrocks (eds.), Conservation of Caribbean Island Herpetofaunas. Volume 2: Regional Accounts of the West Indies. Brill Academic Publishers, Leiden, The Netherlands.

Ernst, C.H. and E.M. Ernst. 2003. Snakes of the United States and Canada. Smithsonian Institution Press, Washington, DC.

Franz, R., G.S. Morgan, and J.E. Davies. 1987. Some recent introductions of reptiles in the Cayman Islands. Herpetological Review 18:10-11.

Hayes, W.K., R.X. Barry, Z. McKenzie, and P. Barry. 2004. Grand Bahama's Brown-headed Nuthatch: A distinct and endangered species. Bahamas Journal of Science 12:21-28.

Henderson, R.W. 1992. Consequences of predator introductions and habitat destruction on amphibians and reptiles in the post-Columbus West Indies. Caribbean Journal of Science 28:1-10.

Henderson, R.W. and M. Breuil. 2012. Lesser Antilles, pp. 148-159. In: R. Powell and R.W. Henderson (eds.), Island lists of West Indian amphibians and reptiles. Bulletin of the Florida Museum of Natural History 51:85-166.

Hodge, K.V.D., E.J. Censky, and R. Powell. 2003. The Reptile and Amphibians of Anguilla, British West Indies. Anguilla National Trust, The Valley.

Hodge, K.V.D., R. Powell, and E.J. Censky. 2011. Conserving the herpetofauna of Anguilla, pp. 3-15. In: A. Hailey, B.S. Wilson, and J. Horrocks (eds.), Conservation of Caribbean Island Herpetofaunas. Volume 2: Regional Accounts of the West Indies. Brill Academic Publishers, Leiden, The Netherlands.

Kairo, M., A. Bibi, O. Cheeseman, K. Haysom, and S. Murphy. 2003. Invasive Species Threats in the Caribbean Region. Report to The Nature Conservancy. CAB International, Wallingford, UK (www.issg.org/database/species/reference_files/kairo\%20et\%20al,\%202003.pdf).

Knapp, C.R., J.B. Iverson, S.D. Buckner, and S.V. Cant. 2011. Conservation of Amphibians and Reptiles in The Bahamas, pp. 53-87. In: A. Hailey, B.S. Wilson, and J. Horrocks (eds.), Conservation of Caribbean Island 
Herpetofaunas. Volume 2: Regional Accounts of the West Indies. Brill Academic Publishers, Leiden, The Netherlands.

Kolbe, J.J., R.E. Glor, L. Rodriguez-Schettino, A. Chamizo-Lara, A. Larson, and J.B. Losos. 2007. Multiple sources, admixture, and genetic variation in introduced Anolis lizard populations. Conservation Biology 21:1612-1625.

Perry, G. and G.P. Gerber 2006. Conservation status of reptiles and amphibians in the U.S. Virgin Islands. Applied Herpetology 3:237-256 (Reprinted 2011, with addendum, pp. 105-127 in: A. Hailey, B.S. Wilson, and J. Horrocks (eds.), Conservation of Caribbean Island Herpetofaunas. Volume 2: Regional Accounts of the West Indies. Brill Academic Publishers, Leiden, The Netherlands).

Perry, G. and R. Platenberg. 2007. Recent additions to the herpetofauna of Little St. James, U.S. Virgin Islands. Applied Herpetology 4:387-389.

Perry, G., J. Pierce, D. Griffin, G. van Buurt, and J. Lazell. 2003. Geographic distribution: Elaphe guttata guttata. Herpetological Review 34:264.

Platenberg, R.J. 2007. Impacts of introduced species on an island ecosystem: Nonnative reptiles and amphibians in the U.S. Virgin Islands, pp. 168-174. In: G.W. Witmer, W.C. Pitt, and K.A. Fagerstone (eds.), Managing Vertebrate Invasive Species: Proceedings of an International Symposium. USDA/APHIS/ WS, National Wildlife Research Center, Fort Collins, Colorado.

Platenberg, R.J. and R.H. Boulon. 2006. Conservation status of reptiles and amphibians in the U.S. Virgin Islands. Applied Herpetology 3:215-235 (Reprinted 2011, with addendum, pp. 407-428 in: A. Hailey, B.S. Wilson, and J. Horrocks (eds.), Conservation of Caribbean Island Herpetofaunas. Volume 2: Regional Accounts of the West Indies. Brill Academic Publishers, Leiden, The Netherlands).

Platenberg, R.J., F.E. Hayes, D.B. McNair, and J.J. Pierce. 2005. A Comprehensive Wildlife Conservation Strategy for the U.S. Virgin Islands. Division of Fish and Wildlife, St. Thomas, U.S. Virgin Islands.

Powell, R. 2006. Conservation of the herpetofauna on the Dutch Windward Islands: St. Eustatius, Saba, and St Maarten. Applied Herpetology 2:293-306 (Reprinted 2011, with addendum, pp. 189-204 in: A. Hailey, B.S. Wilson, and J. Horrocks (eds.), Conservation of Caribbean Island Herpetofaunas. Volume 2: Regional Accounts of the West Indies. Brill Academic Publishers, Leiden, The Netherlands).

Powell, R. and R.W. Henderson. 2003. A second set of addenda to the checklist of West Indian Amphibians ad Reptiles. Herpetological Review 34:341-345.

Powell, R. and R.W. Henderson. 2005. Conservation status of Lesser Antillean reptiles. Iguana 12:2-17.

Powell, R., R.W. Henderson, M.C. Farmer, M. Breuil, A.C. Echternacht, G. van Buurt, C.M. Romagosa, and G. Perry. 2011. Introduced amphibians and reptiles in the Greater Caribbean: Patterns and conservation implications, pp. 63-143. In: A. Hailey, B.S. Wilson, and J.A. Horrocks (eds.), Conservation of Caribbean Island Herpetofaunas. Volume 1: Conservation Biology and the Wider Caribbean. Brill, Leiden, The Netherlands.

Powell, R., R.W. Henderson, and J.S. Parmerlee. 2005. The Reptiles and Amphibians of the Dutch Caribbean: St. Eustatius, Saba, and St. Maarten. St. Eustatius National Parks Foundation (STENAPA), Gallows Bay, St. Eustatius, Netherlands Antilles.

Questel, K. and A. Vitry. 2012. Pantherophis guttatus (Corn Snake). Distribution. Caribbean Herpetology 37:1.

Reynolds, R.G. and M.L. Niemiller. 2010. Island invaders: Introduced amphibians and reptiles of the Turks and Caicos Islands. Reptiles \& Amphibians 17:117-121.

Schwartz, A. and R.W. Henderson. 1991. Amphibians and Reptiles of the West Indies: Descriptions, Distributions, and Natural History. University of Florida Press, Gainesville.

van Buurt, G. 2006. Conservation of amphibians and reptiles in Aruba, Curaçao and Bonaire. Applied Herpetology 3:307-321 (Reprinted 2011, with addendum, pp. 145-159 in: A. Hailey, B.S. Wilson, and J.A. Horrocks (eds.), Conservation of Caribbean Island Herpetofaunas. Volume 1: Conservation Biology and the Wider Caribbean. Brill, Leiden, The Netherlands). 